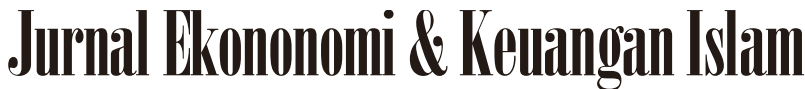

\author{
Available at http://journal.uii.ac.id/index.php/jeki
}

\section{Analisis efektifitas transmisi kebijakan moneter konvensional dan syariah dalam mempengaruhi tingkat inflasi}

\author{
Heri Sudarsono \\ Fakultas Ekonomi, Universitas Islam Indonesia \\ e-mail: heri.sudarsono@uii.ac.id
}

Keywords

Dual Monetary System, IHK, SBIS, PUAS, IHMK

DOI:

10.20885/JEKI.vol3.iss2.art1

\begin{abstract}
The purpose of this research is to analysis the transmission mechanisme of dual monetary system from conventional and sharia to inflation (IHK) using Vector Auto Regression (VAR) methods. The data used in this study is monthly data in the form of time series began in January 2000 to December 2016. Data process employ stationer test, cointegration test, stability test, impulse response functions analysis and forecast error variance decomposition. The result of conventional transmission mechanisme shows that is $S B M K$ effective to promote inflation, but SBI, LOAN, and PUAB are not effective to promote inflation. Meanwhile, the sharia transmission mechanisme indicate that are SBIS and FINCS not effective in drive inflation, while FINC and IHMK effective to boost inflation. Finally, in dual transmission mechanisme shows that LOAN and FINC contribute more than other variables in influencing inflation.
\end{abstract}

\begin{abstract}
Abstrak
Tujuan penelitian ini adalah untuk menganalisa mekanisme transmisi sistem moneter ganda dari konvensional dan syariah terhadap inflasi (IHK) menggunakan metode Vector Auto Regression (VAR). Data yang digunakan dalam penelitian ini adalah data bulanan dalam bentuk time series mulai bulan Januari 2000 hingga Desember. Proses data menggunakan tes stasioner, uji kointegrasi, uji stabilitas, impulse response functions analysis dan forecast error variance decomposition. Hasil uji mekanisme transmisi konvensional menunjukkan bahwa SBMK efektif untuk mendorong inflasi, tetapi SBI, LOAN, dan PUAB tidak efektif untuk meningkatkan inflasi. Di lain pihak, mekanisme transmisi syariah menunjukkan bahwa SBIS dan FINC tidak efektif dalam mendorong inflasi sementara FINC dan IHMK efektif untuk meningkatkan inflasi. Akhirnya, dalam mekanisme transmisi berganda menunjukkan bahwa LOAN dan FINC memiliki kontribusi yang lebih besar dibanding variabel lain dalam mempengaruhi inflasi.
\end{abstract}

\section{Pendahuluan}

Mekanisme transmisi kebijakan moneter merupakan kebijakan yang digunakan untuk mempengaruhi perekonomian. Bank Indonesia (BI) mengunakan enam saluran transmisi kebijakan moneter yaitu uang, kredit, suku bunga, nilai tukar, harga aset dan ekspektasi. BI mengunakan enam saluran tersebut untuk memenuhi target kebijakan moneter, yaitu stabilitas harga, pertumbuhan ekonomi, kesempatan kerja dan keseimbangan negeraca pembayaran. Untuk memenuhi target kebijakan tersebut BI mengeluarkan instrumen kebijakan moneter, yaitu operasi pasar terbuka (open market operation), fasilitas diskon (discount rate), rasio cadangan wajib (reserve requirement ratio) dan imbuan moral (moral persuasion) (Warjiyo, 2004).

Kebijakan moneter melalui jalur ekspektasi cenderung lebih mendapatkan perhatian dibanding lima jalur lain. Dalam teori ekspektasi dipahami bahwa masyarakat cukup rasional dalam mengantisipasi kemungkinan terjadinya inflasi di masa depan. Oleh karena itu, masyarakat cenderung lebih banyak berbelanja pada saat ini dibanding di masa akan datang karena kemampuan belanja di masa datang turun. Ekspektasi inflasi akan mendorong kenaikan tingkat bunga. Apabila tingkat bunga naik lebih kecil dibanding dengan kenaikan harga akan menjadikan kekayaan non riil menurun. Dilain pihak, menyimpan kekayaan dalam bentuk aset riil menjadi pilihan masyarakat bila kenaikan inflasi relatif lebih rendah dari kenaikan harga. (Widayat et al, 2002; Hasibuan, 2013).

Kebijakan moneter ekspansif memiliki tujuan untuk menjaga stabilitas ekonomi, menjaga stabilitas harga, meningkatkan kesempatan kerja dan memperbaiki posisi neraca perdagangan dan pembayaran. Kebijakan moneter ekspansif digunakan untuk mengantisipasi adanya inflasi dan turunnya nilai tukar dikarenakan adanya ekspektasi inflasi (Pohan, 2008). Upaya yang dilakukan pemerintah untuk meminimalisir ekspektasi inflasi adalah dengan membeli surat berharga pemerintah, menurunkan tingkat bunga diskonto atau menurunkan besaran cadangan wajib. Kebijakan ini akan meningkatkan kapasitas produksi sehingga mendorong kenaikan 
belanja barang dan jasa dari dalam negeri dan luar negeri. Kenaikan volume perdagangan ke luar negeri akan menambah jumlah mata uang asing terhadap jumlah rupiah sehingga meningkatkan nilai kurs (Natsir, 2011).

Indonesia mengunakan sistem perbankan ganda (dual banking system) setelah dikeluarkan UU No 10 tahun 1998. Perbankan menganda adalah pemberlakukan sistem perbankan dengan mengunakan sistem konvensional dan sistem syariah. Undang-undang ini memberi kesempatan bagi bank umum konvensional untuk memberikan layanan kepada masyarakat dengan prinsip syariah. (Siamat, 2005). Unit layanan syariah atau unit usaha syariah (UUS) di perbankan umum konvensional digunakan untuk melayani transaksi keuangan pada masyarakat yang lebih memilih prinsip syariah. Keadaan ini yang menjadikan instrumen kebijakan moneter tidak hanya mengunakan prinsip bunga tetapi juga prinsip syariah, yaitu bagi hasil dan jual beli. (Sudarsono, 2015).

Pada transmisi kebijakan moneter konvensional alur transmisi kebijakan melalui enam saluran yaitu jalur uang, kredit, suku bunga, nilai tukar, harga aset dan ekspektasi. Namun keenam jalur transmisi pada kebijakan moneter konvensional tidak digunakan pada kebijakan transmisi moneter syariah. Perbedaan utama pada jalur suku yang tidak dapat dapat digunakan dalam transmisi moneter syariah karena konsep bunga dilarang dalam ajaran Islam (Ascarya, 2007, Hasanah et al, 2008). Jika dalam instrumen kebijakan moneter konvensional dikenal dengan SBI dan PUAB, tetapi dalam syariah mengenal SBI Syariah (SBIS) dan PUA syariah (PUAS). SBIS mengunakan akad jualah, namun demikian SBIS dapat diterbitkan oleh BI dengan akad musyarakah, mudharabah, wadiah, qord dan wakalah. Sedangkan PUAS terdiri dari Investasi Musharakah Antarbank (SIMA) dan Sertifikat Perdagangan Komiditi Berdasarkan Prinsip Syariah (SIKA).

Beberapa penelitian tentang efektifitas instrumen kebijakan moneter konvensional dan syariah dalam mempengaruhi perekonomian melalui enam jalur transmisi sudah dilakukan sejak 2007. Penelitian dengan topik yang sama dilakukan pada tahun-tahun berikut dengan perbedaan pada jumlah variabel, jumlah observasi dan metode penelitian yang digunakan. (Ascarya, 2007; Hasanah, et al, 2008; Rusydiana, 2009; Natsir, 2011; Ascarya, 2012; Noviasari , 2012, Magdalena \& Pratomo, 2013; Rabin \& Hermawan, 2013; Utama \& Septiani, 2017). Penelitian ini kembali akan mengkaji efektifitas kebijakan transmisi moneter berganda melalui jalur ekspektasi inflasi. Adapun rumusan penelitian adalah apakah perbedaan efektifiktas pengaruh transmisi kebijakan moneter konvensional dan syariah terhadap tingkat inflasi di Indonesia periode 2010-2016.

Dalam penelitian yang dilakukan oleh Utama \& Septiani (2017) tentang transmisi jalur suku bunga langsung dan tidak langsung terhadap tingkat bunga ritel bank. Variabel yang digunakan adalah suku bunga BI rate, suku bunga dari Pasar Uang Antar Bank (PUAB), simpanan, dan pinjaman. Temuan dalam penelitian tersebut menunjukkan bahwa jalur transmisi langsung lebih cepat mempengaruhi inflasi melalui bunga ritel bank dibandingkan jalur transmisi tidak langsung. Namun, kedua jalur transmisi saling melengkapi walaupun kebijakan suku bunga BI rate lebih stabil daripada suku bunga langsung. Penelitian ini menunjukkan hasil yang sama dengan penelitian Tang et al, (2015) di Malaysia dan Yan \& Samba (2010) di negara Asia dimana tingkat bunga langsung lebih efektif dalam mempengaruhi tingkat inflasi. Tetapi, hasil berbeda ditemukan Tai \& Sek, (2011) dan Kobayashi (2008) menemukan bahwa kebijakan transmisi moneter pemerintah lewat jalur suku bunga tidak berpengaruh langsung terhadap tingkat inflasi.

Magdalena \& Pratomo (2013) menemukan dari hasil impulse respon pada transmisi moneter konvensional menunjukkan bahwa variabel suku bunga modal kerja dan PUAB memberikan pengaruh positif pada terhadap tingkat inflasi, sedangkan tingkat SBI dan LOAN memberikan pengaruh negatif. Sementara itu, transmisi moneter syariah menunjukkan bahwa SBIS, PUAS, dan imbal hasil modal kerja memberikan pengaruh positif terhadap inflasi. Dari hasil variance decomposition menunjukkan bahwa seluruh variabel konvensional kecuali suku bunga modal kerja mempengaruhi inflasi dan LOAN memberikan kontribusi yang paling besar. Di lain pihak, variabel syariah hampir semua variabel tidak memiliki pengaruh terhadap inflasi. Hasil yang berbeda ditunjukkan pada penelitian Sugiono et al (2015) berdasarkan analisis impulse response menunjukkan bahwa PUAS, SBIS dan pembiayaan bank syariah memiliki hubungan negatif dalam jangka pendek terhadap tingkat inflasi. Sementara itu, berdasarkan analisis variance decomposition menunjukkan bahwa PUAS, SBIS dan FIN memiliki kontribusi yang rendah terhadap inflasi.

Penelitian Ascarya (2012) menyimpulkan bahwa secara keseluruhan gejolak SBI, PUAB, suku bunga dan kredit berpengaruh negatif terhadap tingkat inflasi dan pertumbuhan ekonomi. Pada sisi lain, kebijakan transmisi moneter syariah menunjukkan bahwa gejolak pada SBIS, PUAS dan pembiayaan syariah berdampak positif terhadap inflasi dan pertumbuhan ekonomi. Dalam kaitannya dengan temuan tersebut dalam penelitian Noviasari (2012) menunjukkan bahwa transmisi kebijakan moneter konvensional lebih efektif dalam mempengaruhi inflasi. Hubungan negatif yang terjadi antara SBI dan inflasi selama periode penelitan menunjukkan bahwa kenaikan SBI akan meningkatkan pendanaan dan menjadi mengurang pinjaman di bank konvensional. Bila pembiayaaan turunnya maka optimalisasi produksi barang dan jasa menurun sehingga pendapatan masyarakat berkurang.

Perubahan kebijakan moneter melalui gejolak SBI menurut Natsir (2011) akan mempengaruhi likuiditas terhadap tingkat suku bunga pasar uang. Kenaikan suku bunga pasar akan mempengaruhi turunnya tingkat 
investasi dan konsumsi dan akhirnya berpengaruh terhadap turunnya inflasi. Penelitian ini di dukung oleh penelitian Rusydiana (2009) yang menemukan adanya hubungan negatif antara SBI dengan besaran pinjaman pada bank konvensional dan pembiayaan bank syariah. Berhubungan dengan penelitian tersebut Rabin \& Hermawan (2013) menemukan bahwa kontribusi SBI terhadap tingkat inflasi cukup besar. Hal ini menunjukkan kebijakan moneter melalui BI rate cukup efektif dalam mempengaruhi besaran inflasi.

\section{Metode Penelitian}

Penelitian ini mengunakan data bulanan yang bersumber dari Statistika Ekonomi dan Keuangan Indonesia pada Bank Indonesia (SEKI-BI) dan Biro Pusat Statistik (BPS). Data yang digunakan adalah data bank konvensional dan bank syariah dari Januari 2010 sampai Desember 2017. Alasan mengunakan data pada periode tersebut adalah karena alasan kelengkapan data, adanya beberapa penelitian yang relatif sama kegunakan basis data periode 2010-2015 dan dalam periode tersebut BI dan OJK telah mengeluarkan beberapa kebijakan yang secara teoritik mempengaruhi variabel yang di gunakan.

Variabel yang digunakan adalah indek harga konsumen (IHK) sebagai proksi dari tingkat inflasi, Sertifikat Bank Indonesia (SBI) dan Sertifkat Bank Syariah (SBIS) sebagai proksi surat berharga pemerintah. Sedangkan total pinjaman bank konvensional (LOAN) dan pembiayaan bank syariah (FINC) adalah jumlah pinjaman dan pembiayaan yang dikeluarkan oleh perbankan konvensional dan syariah minus BPRS. Tingkat bunga menggunakan tingkat bunga Pasar Uang Antar Bank (PUAB) dan Pasar Uang Antar Bank Syariah (PUAS). Dan, yang terakhir adalah tingkat suku bunga modal kerja (SBMK) untuk bank konvensional dan untuk bank syariah mengunakan tingkat imbal hasil modal kerja (IHMK).

Vector Autoregression (VAR) digunakan sebagai alat analisis penelitian ini untuk mengetahui hubungan dinamis yang saling menyebabkan di antara variabel di dalam model. Dengan mengunakan metode VAR dapat diketahui hubungan kausalitas antara variabel IHK, SBI, LOAN, PUAB, SBMK pada jalur konvensional, dan antara variabel IHK SBIS. FINC, PUAS dan IHMK untuk jalur syariah. Disamping itu, dengan VAR dapat diketahui tengang waktu (lag) masing-masing variabel dalam mempengaruhi variabel yang lain sehingga dapat diketahui efektifitas kebijakan moneter BI dalam mempengaruhi variabel di dalam model. (Enders, 2004).

Langkah awal dalam penelitian ini adalah mengetahui apakah data yang digunakan unsur akar unit dengan uji stasioner. Apabila data mengandung akar unit maka model akan sulit diestimasi karena tren data tersebut bersifata stokastik atau berfluktuatif tidak disekitar nilai rata-rata yang akan sulit diestimasi. Data memiliki kecenderungan nilai rata-rata dan varian dari data time series tidak mengalami perubahan secara sistematik sepanjang waktu, atau rata-rata dan variannya konstan. Untuk menguji adanya data yang stasioner atau tidak stasioner digunakan Augmented Dickey-Fuller (ADF) test dan kemudian hasil ADF dibandingkan dengan McKinnon Critical Value (Gujarati, 2004).

Setelah dilakukan uji stasioner, langkah berikutnya adalah menentukan panjang lag optimal. Penentuan panjang lag optimal bertujuan untuk untuk menghilangkan persoalan autokorelasi dalam sistem VAR yang sensitif terhadap panjang lag. Dengan begitu pengunaan lag optimal diharapkan masalah autokorelasi tidak lagi muncul. Penentuan panjang lag mengunakan kriteria Akaike Information Criterion (AIC), Schwarz Information Criterion (SIC) atau Hannan Quinnon (HQ).

Langkah berikutnya dilakukan uji kointegrasi untuk mengetahui hubungan antar variabel dalam jangka panjang. Adanya hubungan jangka panjang diantara variabel apabila terdapat kointegrasi pada variabel yang digunakan di dalam model. Untuk mengetahui adanya kointegrasi antara variabel dilakukan uji Johansen. Dalam uji Johansen bila terindikasi nilai trace statistic dan max eigen statistic lebih tinggi dari nilai kritisnya menunjukkan adanya kointegrasi di dalam model.

Impulse Response Function (IRF) digunakan untuk mengetahui pengaruh goncangan standar deviasi terhadap perubahan dari variabel endogen pada model untuk periode sekarang dan yang akan datang. Dengan kata lain, IRF digunakan untuk menyelusuri respon waktu sekarang dan waktu yang akan datang pada setiap variabel akibat goncangan suatu variabel dengan mengunakan informasi di masa lalu. Melalui struktur dinamik VAR secara langsung variabel inovasi akan berpengaruh terhadap variabel yang bersangkutan dan kemudian ke variabel yang lain.

Forecast Error Variance Decomposition (FEVD) menjelaskan inovasi pada suatu variabel terhadap variabel yang lain dalam model. FEVD akan menjelaskan proporsi pergerakan secara berurutan yang diakibatkan oleh guncangan sendiri dan variabel lain. FEVD digunakan untuk mengetahui kontribusi setiap variabel dalam model karena adanya fluktuasi atau perubahan variabel tertentu di dalam sistem VAR/VECM. 


\section{Hasil dan Analisis}

\section{Hasil Uji Stasioner}

Langkah pertama untuk mengetahui hasil penelitian ini adalah dengan menguji apakah masing-masing variabel memiliki pola yang normal atau stasioner. Hasil uji stasioner menunjukkan bahwa pada tingkat level menunjukkan bahwa SBI dan IHMK bersifat stasioner sedangkan lainnya menunjukkan tidak stasioner. Dikarenakan ada unsur tidak stasioner pada beberapa variabel pada tingkat level, uji stasioner dilanjutkan pada tingkat first difference. Hasil uji unit root pada tingkat first difference menunjukkan bahwa seluruh variabel dalam model setelah diturunkan pada derajat integrasi satu (1) mencapai derajat stasioner.

Tabel 1. Hasil Uji Stasioneritas - ADF Test pada First Difference

\begin{tabular}{lcccc}
\hline \multirow{2}{*}{ Variabel } & \multicolumn{2}{c}{ Level } & \multicolumn{2}{c}{ First Different } \\
\cline { 2 - 5 } & $\begin{array}{c}\text { Dickey Fuller } \\
\text { Test }\end{array}$ & Probabilitas & $\begin{array}{c}\text { Dickey } \\
\text { Fuller Test }\end{array}$ & Probabilitas \\
\hline IHK & -2.158915 & 0.2228 & -8.947041 & 0.0000 \\
SBI & -2.673959 & 0.0831 & -6.964155 & 0.0000 \\
SBIS & -2.262811 & 0.1865 & -6.239024 & 0.0000 \\
PUAB & -2.185872 & 0.2130 & -4.596608 & 0.0003 \\
PUAS & -2.117494 & 0.2385 & -12.63921 & 0.0001 \\
LOAN & -0.789707 & 0.8163 & -5.154897 & 0.0000 \\
FINANCING & -0.916375 & 0.7783 & -5.154897 & 0.0000 \\
SBMK & -1.638465 & 0.4584 & -2.728698 & 0.0737 \\
IHMK & -7.620637 & 0.0000 & -15.33187 & 0.0001 \\
\hline
\end{tabular}

\section{Hasil Uji Lag Optimum}

Untuk menghilangkan masalah autokorelasi dalam sistem VAR dilakukan pengujian panjang lag optimum. Dari pengujian lag pada transmisi moneter konvensional menunjukkan bahwa lag optimal pada lag 1 . Pada tabel 2 menunjukkan lag 1 merupakan lag terpendek dari dari Final Prediction Error (FPE), Schwarz Information Criterion (SC) dan Hannan-Quinn Information Criterion (HQ), sedangkan Akaike information criterion (AIC) terletak pada lag 7.

Tabel 2. Hasil Penentuan Panjang Lag pada Transmisi Moneter Konvensional

\begin{tabular}{ccccccc}
\hline Lag & LogL & LR & FPE & AIC & SC & HQ \\
\hline 0 & -1191.985 & NA & 21881545 & 31.09053 & 31.24273 & 31.15141 \\
1 & -705.7696 & 896.6580 & $137.4273^{*}$ & 19.11090 & $20.02407^{*}$ & $19.47616^{*}$ \\
2 & -687.0295 & 32.12579 & 163.0322 & 19.27349 & 20.94764 & 19.94314 \\
3 & -665.8666 & 33.53093 & 183.9158 & 19.37316 & 21.80828 & 20.34718 \\
4 & -643.6251 & 32.35114 & 205.6611 & 19.44481 & 22.64091 & 20.72322 \\
5 & -614.6827 & 38.33931 & 198.5253 & 19.34241 & 23.29948 & 20.92520 \\
6 & -582.2640 & $38.73405^{*}$ & 181.5996 & 19.14971 & 23.86776 & 21.03689 \\
7 & -548.2440 & 36.22906 & 167.3016 & $18.91543^{*}$ & 24.39446 & 21.10699 \\
\hline
\end{tabular}

Sementara itu dari pengujian lag transmisi moneter syariah menunjukkan bahwa lag optimal terdapat pada lag 2. Pada tabel 3, menunjukkan indikator penentuan lag optimal menunjukkan FPE, AIC, SC dan HQ terpendek terletak pada lag 2.

Tabel 3. Hasil Penentuan Panjang Lag pada Transmisi Moneter Syariah

\begin{tabular}{ccccccc}
\hline Lag & LogL & LR & FPE & AIC & SC & HQ \\
\hline 0 & -1546.837 & NA & $2.20 \mathrm{e}+11$ & 40.30745 & 40.45964 & 40.36832 \\
1 & -1243.185 & 559.9816 & $1.59 \mathrm{e}+08$ & 33.06973 & 33.98290 & 33.43499 \\
2 & -1121.878 & 207.9542 & $13107781^{*}$ & $30.56826^{*}$ & $32.24241^{*}$ & $31.23791^{*}$ \\
3 & -1110.153 & 18.57697 & 18894735 & 30.91307 & 33.34820 & 31.88710 \\
4 & -1087.444 & 33.03237 & 20873289 & 30.97256 & 34.16866 & 32.25097 \\
5 & -1051.715 & $47.32809^{*}$ & 16893118 & 30.69391 & 34.65098 & 32.27670 \\
6 & -1026.111 & 30.59260 & 18444796 & 30.67820 & 35.39625 & 32.56538 \\
7 & -1000.673 & 27.08981 & 21235722 & 30.66683 & 36.14585 & 32.85839 \\
\hline
\end{tabular}




\section{Hasil Uji Stabilitas VAR}

Uji stabilitas VAR digunakan untuk menghitung akar-akar fungsi polinomial atau yang dikenal roots of charactersitic polynomial. Suatu sistem VAR dikatakan stasioner apabila seluruh roots-nya memiliki modulus lebih kecil dari satu dan terletak di dalam lingkaran. Berdasarkan uji stabilitas VAR pada gambar 1 , transmisi moneter konvensional dan transmisi moneter Islam menunjukkan nilai modulus pada model masuk dalam lingkaran. Berdasarkan hasil tersebut dapat disimpulkan bahwa model VAR stabil sehingga bisa dilakukan uji impulse response dan variance decomposition pada model ini.

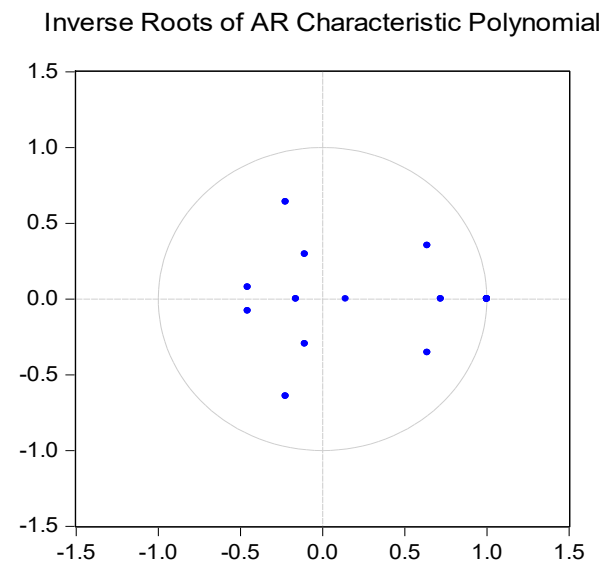

Inverse Roots of AR Characteristic Polynomial

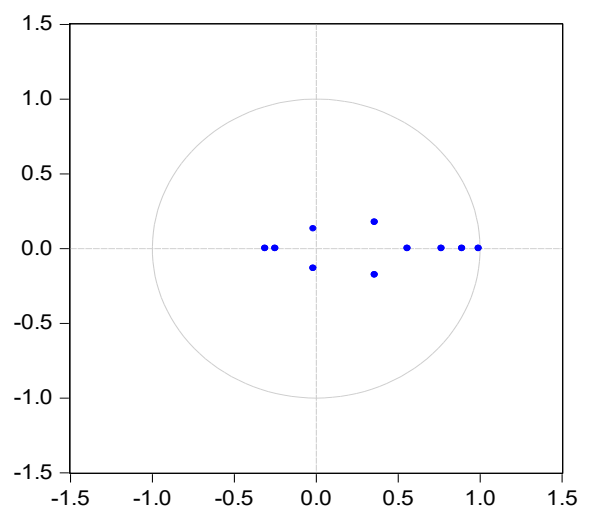

Gambar 1. Uji Stabilitas Trasmisi Moneter Konvensional dan Syariah

\section{Hasil Uji Kointegrasi}

Hasil uji kointegrasi dengan mengunakan pengujian Johansen cointegration dengan uji trace statistic dan maxeigenvalues statistic pada transmisi moneter konvensional dan transmisi moneter Islam menunjukkaan adanya hubungan kointegrasi pada tingkat signifikan 5 persen. Hal ini ditunjukan dari perbandingan nilai trace statistic-nya dan max-eigenvalues statistic-nya yang lebih besar dibandingkan nilai kritisnya dengan demikian terdapat hubungan jangka panjang antara variabel IHK, SBI, LOAN, PUAB dan SBMK pada persamaan transmisi moneter konvensional, dan antara IHK, SBIS, FINC, PUAS dan IHMK pada persamaan transmisi moneter Islam.

Tabel 4. Uji Kointegrasi Transmisi Moneter Konvensional

\begin{tabular}{ccccc}
\hline $\begin{array}{c}\text { Hypothesized } \\
\text { No. of CE(s) }\end{array}$ & Eigenvalue & $\begin{array}{c}\text { Trace } \\
\text { Statistic }\end{array}$ & $\begin{array}{c}\mathbf{0 . 0 5} \\
\text { Critical Value }\end{array}$ & Prob.** \\
\hline None $*$ & 0.304514 & 78.87457 & 69.81889 & 0.0079 \\
At most $1 *$ & 0.253622 & 49.45984 & 47.85613 & 0.0351 \\
At most 2 & 0.195612 & 25.76545 & 29.79707 & 0.1359 \\
At most 3 & 0.091318 & 8.133875 & 15.49471 & 0.4512 \\
At most 4 & 0.004647 & 0.377296 & 3.841466 & 0.5391 \\
\hline
\end{tabular}

Berdasarkan tabel 4 dan tabel 5 menunjukkan bahwa terdapat minimal satu rank kointegrasi dimana trace statistik lebih besar dari critical value 5\%. Dalam tabel tersebut menunjukkan bahwa terdapat minimal satu persamaan kointegrasi yang mampu menerangkan keseluruhan masing-masing model.

Tabel 5. Uji Kointegrasi Transmisi Moneter Syariah

\begin{tabular}{ccccc}
\hline $\begin{array}{c}\text { Hypothesized } \\
\text { No. of CE(s) }\end{array}$ & Eigenvalue & $\begin{array}{c}\text { Trace } \\
\text { Statistic }\end{array}$ & $\begin{array}{c}\mathbf{0 . 0 5} \\
\text { Critical Value }\end{array}$ & Prob.** \\
\hline None $*$ & 0.304514 & 78.87457 & 69.81889 & 0.0079 \\
At most $1 *$ & 0.253622 & 49.45984 & 47.85613 & 0.0351 \\
At most 2 & 0.195612 & 25.76545 & 29.79707 & 0.1359 \\
At most 3 & 0.091318 & 8.133875 & 15.49471 & 0.4512 \\
At most 4 & 0.004647 & 0.377296 & 3.841466 & 0.5391 \\
\hline
\end{tabular}




\section{Uji Impulse Response Function (IRF)}

\section{Uji IRF transmisi kebijakan moneter konvensional}

Dalam gambar 2 menunjukkan bahwa sumbu vertikal pada gambar IRF menjelaskan standar deviasi yang digunakan untuk mengukur berapa besar respon yang akan diberikan oleh SBI, LOAN, PUAB dan SBMK apabila terjadi shock terhadap IHK. Sedangkan, sumbu horizontal menunjukkan lamanya waktu respon variabel dalam model jika ada shock pada IHK. Bila respon IHK di atas sumbu horizontal menunjukkan bahwa shock akan berpengaruh positif. Sebaliknya apabila respon IHK dibawah sumbu horizontal menunjukkan bahwa shock berpengaruh negatif.

Analisis IRF di transmisi moneter konvensional menunjukkan bahwa dalam 20 bulan mendatang, respon tertinggi IHK adalah IHK itu sendiri, yang diperkirakan akan stabil pada standar deviasi sepuluh. Respon IHK terhadap SBI pada awal periode ke-4 menunjukkan pengaruh positif namun kemudian respon IHK terhadap SBI negatif pada periode ke-5 dan menunjukkan kondisi stabil pada standar deviasi ke-9. Meningkatkan bunga SBI merupakan bagian dari kebijakan BI untuk mengendalikan tingkat inflasi. Kenaikan suku bunga SBI adalah upaya pemerintah untuk menyerap jumlah uang beredar dari masyarakat. Namun, kenaikan tingkat suku bungan SBI akan meningkatkan bunga tabungan dan pinjaman. Keadaan ini menyebabkan jumlah dana bank yang bersumber dari tabungan meningkat, namun jumlah dana yang dikeluarkan dalam bentuk pinjaman akan berkurang.

Response to Cholesky One S.D. Innovations

Response of IHK to IHK

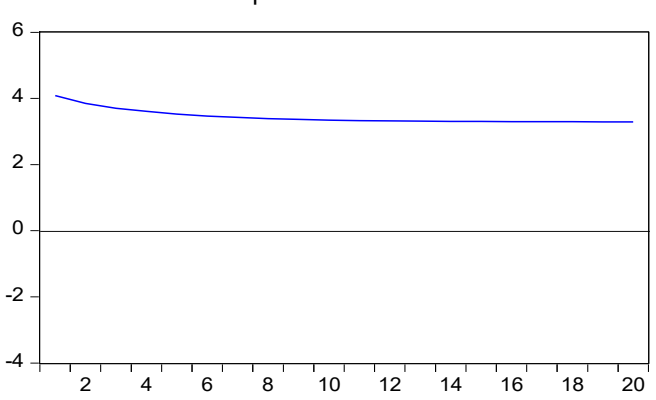

Response of IHK to LOAN

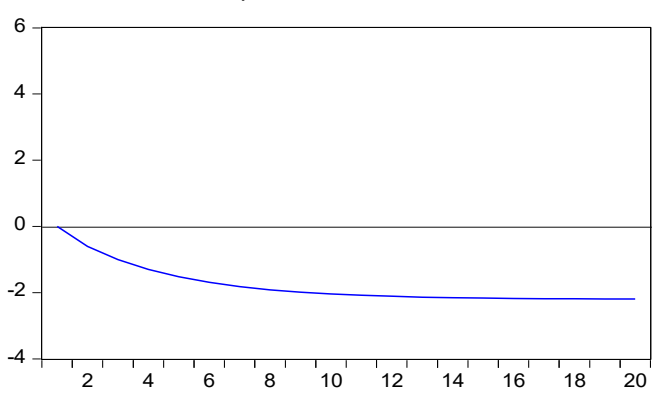

Response of IHK to SBMK

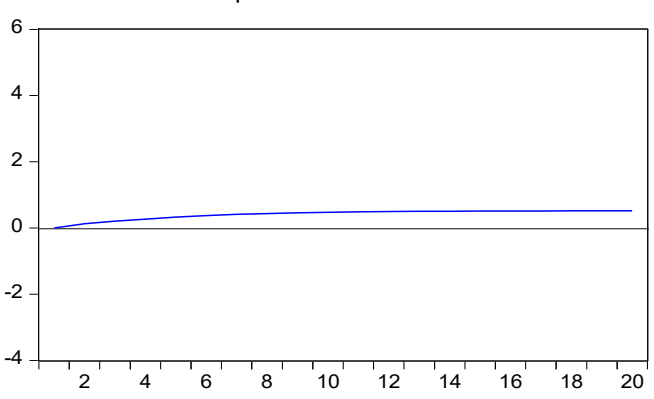

Response of IHK to SBI

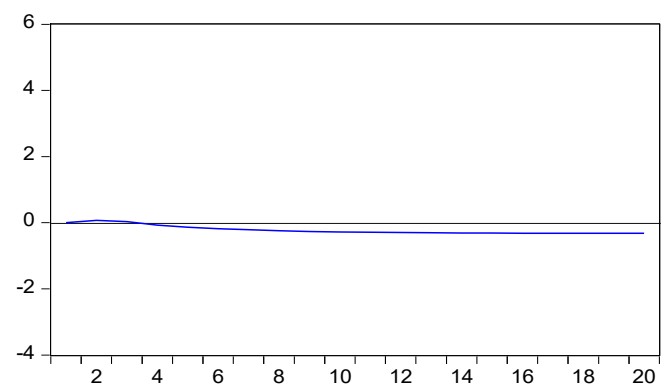

Response of IHK to PUAB

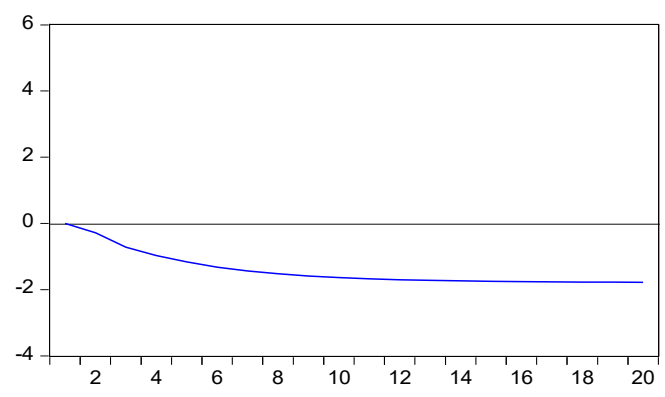

Gambar 2. Impulse Response Transmisi Moneter Konvensional

Sementara guncangan variabel LOAN direspon negatif oleh IHK dengan perkiraan stabil mencapai standar devisi ke 18. Keadaan ini bisa diartikan bahwa kenaikan pinjaman bank konvensional direspon negatif oleh tingkat inflasi. Keadaan ini bisa terjadi karena manajemen bank konvensional mampu mengontrol jumlah 
pinjaman yang disalurkan ke sektor konsumtif dan produktif. Keadaan ini yang menjadikan tingkat produksi relatif stabil dikarenakan input produksi yang diperoleh dari bank sesuai dengan kebutuhan. Respon negatif IHK terhadap pergerakan LOAN bisa diartikan bahwa nilai pinjaman bank konvensional 2010-2016 tidak begitu berpengaruh terhadap berpengaruh. Keadaan ini disebabkan selama tahun 2010-2016 kondisi makro ekonomi relatif stabil sehingga tidak banyak mempengaruhi terhadap besaran inflasi.

Sementara itu, IHK merespon negatif terhadap goncangan yang terjadi pada PUAB dan kondisi stabil pada standar deviasi ke 15. BI menggunakan suku bunga Pasar Uang Antara Bank (PUAB) sebagai salah satu sasaran untuk mengendalikan tingkat inflasi. BI selalu berusaha menjaga kebutuhan likuiditas secara seimbang agar pergerakan suku bunga PUAB tidak terlalu jauh dari dari ketentuan anchor-nya. Kondisi likuiditas di PUAB relatif terkendali walaupun nilai terendah sempat terjadi di Mei 2012 dengan nilai 7.41\%, sedangkan tertinggi pada Desember 2015 dengan nilai 15.62\%. Kenaikan suku bunga PUAB sempat terjadi pasca kebijakan stablitasi nilai tukar sebagai dampak dari pengurangan volume foreign exchange (FX) swap. Namun, rata-rata tertimbang suku bunga PUAB kembali turun hingga mendekati deposit facility (DF) rate. Turunnya nilai PUAB akan menyebabkan tingkat bunga bank relatif tinggi sehingga menurunkan input produksi yang menyebabkan turunnya tingkat inflasi.

Respon positif ditunjukkan IHK terhadap goncangan suku bunga modal kerja (SBMK) dan kondisi stabil pada standar deviasi ke 10. Kenaikan suku bunga pada pembiayaan usaha meningkatkan skala produksi sehingga meningkat output produksi. Dampaknya harga barang dan jasa akan relatif murah sehingga meningkat jumlah permintaan akan barang dan jasa. Meningkatkan permintaan barang dan jasa akan menyebabkan meningkatkan inflasi dari sisi permintaan atau demand pull inflation. Selama masa observasi 2010-2016 menunjukkan bahwa SBMK pada 2016 memiliki nilai 11.36\%, nilai ini lebih tinggi dibanding tahun sebelumnya yang rata-rata di atas $12 \%$. Sementara itu, IHK menunjukkan peningkatan pada 2016 walaupun sempat ada kenaikan IHK yang cukup tinggi di tahun 2010-2013.

\section{Uji IRF transmisi kebijakan moneter syariah}

Analisis IRF di transmisi moneter syariah menunjukkan bahwa di dalam 20 bulan mendatang, respon tertinggi adalah respon IHK terhadap IHK itu sendiri, yang diperkirakan akan stabil pada standar deviasi kelima. Respon positif IHK terhadap SBIS dimulai pada awal periode ke-4 menunjukkan pengaruh positif namun kemudian respon IHK terhadap SBIS negatif dan menunjukkan kondisi stabil pada standar deviasi ke-10. Artinya semakin tinggi imbal hasil SBIS yang ditetapkan BI akan menurunkan besaran IHK. Meningkatkan imbal hasil SBIS akan direspon oleh bank syariah dengan menyalurkna dananya dalam bentuk SBIS. Hal ini terjadi karena SBIS dianggap menguntungkan dibandingkan dengan menyalurkan dana dalam bentuk pembiayaan maka bank syariah akan menyimpan dananya ke BI. Jika bank syariah lebih banyak menyalurkan dan pada pasif income di SBIS maka dana yang di salurkan dalam bentuk pembiayaan cenderung akan menurun dan akselerasi pendanan pada bidang usaha pun rendah sehingga berdampak rendah pada tingkat inflasi.

Sementara guncangan variabel FINC direspon positif oleh IHK dari awal periode sampai periode ke 20 dan mencapai kondisi stabil pada standar devisi ke-10. Keadaan ini bisa diartikan bahwa pada saat inflasi meningkat meningkatkan pembiayaan bank syariah dan sebaliknya. Inflasi bisa dimaknai meningkatnya kemampuan belanja barang dan jasa masyarakat karena meningkatnya pendapatan. Tingkat konsumsi masyarakat yang meningkat memberi peluang bagi bank syariah untuk memberikan variasi pembiayaan kepada masyarakat. Dalam kondisi seperti ini, bank syariah akan lebih banyak menawarkan pembiayan pada sektor konsumtif dan produktif dalam rangka menangkap peluang memperoleh pendapatan secara maksimal. Namun dalam jangka panjang, kenaikan inflasi akan direspon pemerintah dengan meningkatkan imbal hasil SBIS yang akhirnya akan mempengaruhi kenaikan imbal hasil pembiayaan di bank syariah.

Sementara itu, IHK merespon negatif terhadap goncangan yang terjadi pada PUAS dan kondisi stabil pada standar deviasi ke-15. PUAS digunakan untuk menambah alternatif pemenuhan kebutuhan likuditas di perbankan syariah dengan cara menjual surat berharga syariah dengan janji membeli kembali (repurchase agreement) atau transaksi repo syariah. Namun bank syariah lebih selektif memanfaat instrumen PUAS karena faktor kecukupan likuiditas yang dilihat dari besaran dana yang masuk dengan dengan dana yang salurkan dalam bentuk pembiayaan atau Financing to Debet Rasio (FDR) di masing-masing bank syariah. Disamping itu, bank syariah cenderung lebih memanfaatkan fasilitas repuchasing agreement (repo), gadai SBIS atau Fasilitas Simpanan Bank Indonesia Syariah (FASBIS) yang pendanaannya lebih cepat cair dan beresiko rendah. Oleh karenanya, rendahnya transaksi bank syariah yang mengunakan instrumen PUAS menyebabkan dampak PUAS terhadap IHK relatif rendah. 
Response to Cholesky One S.D. Innovations

Response of IHK to IHK

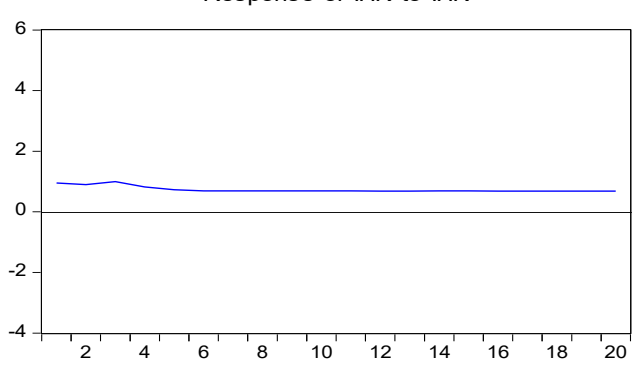

Response of IHK to FINC

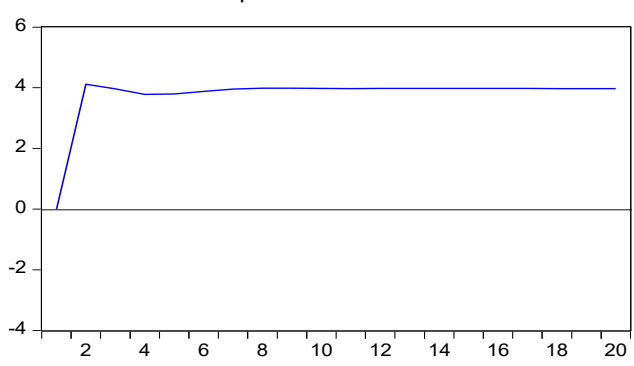

Response of IHK to IHKM

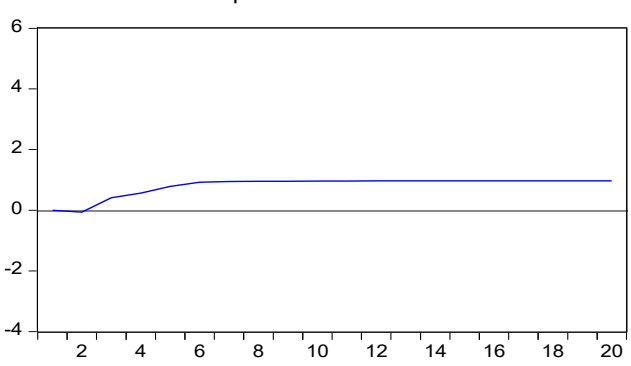

Response of IHK to SBIS

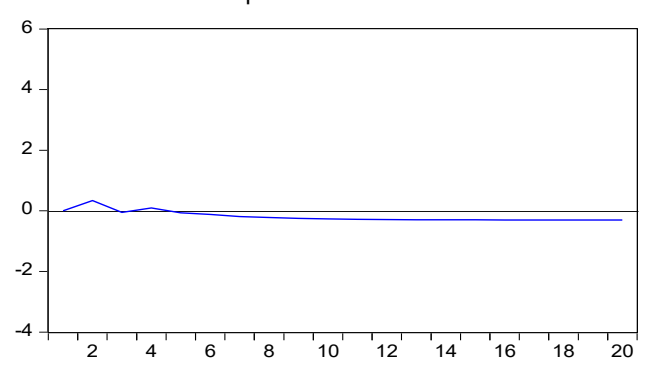

Response of IHK to PUAS

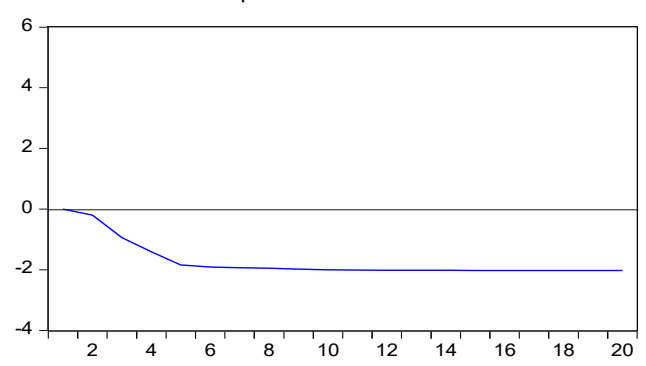

Gambar 3. Impulse Response Transmisi Moneter Syariah

IHK merespon positif terhadap goncangan IHMK pada standar deviasi ke-2 dan kondisi stabil pada standar deviasi ke-8. Bank syariah lebih banyak menyalurkan pembiayan pada sektor konsumtif dikarenakan memiliki resiko lebih rendah dibanding dengan sektor produktif. Hal ini disebabkan karena pengelolaan konsumtif yang kebanyakan mengunakan skim jual beli (murabaha) memiliki mekanisme yang lebih sederhana dibanding skim bagi hasil (mudharabah dan musharakah). Disamping itu, kepastian pembiayaan sektor konsumtif untuk menghasilkan keuntungan dengan minim resiko lebih tinggi dibanding dengan pembiayaan sektor produktif. Namun demikian respon positif IHK terhadap goncangan IHMK bisa dimaknai bahwa meningkatnya kemampuan masyarakat berbelanja menjadi bank syariah lebih lunak dalam mengeluarkan pembiayaan ke sektor produktif.

\section{Variance Decomposition (FEVD)}

FEVD transmisi kebijakan moneter konvensional

Variance decomposition (VD) pada transmisi kebijakan moneter konvensional untuk mengetahui kontribusi variabel SBI, LOAN, PUAB dan SBMK terhadap perubahan IHK pada beberapa periode mendatang. Tabel 10, analisis VD menunjukkan bahwa variabel yang diperkirakan akan memiliki kontribusi paling besar terhadap IHK pada duapuluh bulan kedepan adalah IHK sendiri yang diikuti oleh kontribusi LOAN, PUAD, SBMK dan kemudian SBI. Dilihat dari trend setiap periode pada variance decomposition menunjukkan bahwa trend IHK cenderung turun dari periode ke periode. Sedangkan trend LOAN, PUAB, SBMK dan SBI cenderung mengalami kenaikan dari periode ke periode.

Besarnya kontribusi LOAN terhadap IHK dapat dilihat dari besaran trend dari periode 1 sampai periode 20. Besaran kredit yang dikeluarkan bank konvensional berdampak bagi peningkatan output produksi. Meningkatnya output produksi menurunkan harga barang dan jasa sehingga meningkat permintaan. Keadaan ini akan mempengaruhi menurunkan nilai uang terhadap barang sehingga menjadi jumlah uang beredar (JUB) 
bertambah dan inflasipun meningkat. Sementara setelah LOAN, PUAB merupakan variabel yang memberikan kontribusi terhadap besaran IHK. Trend IHK yang meningkat relatif stabil dari dari bulan kedua sampai bulan keduapuluh.

Tabel 10. Variance Decomposition Transmisi Moneter Konvensional

\begin{tabular}{ccccccc}
\hline Period & S.E. & IHK & SBI & LOAN & PUAS & SBMK \\
\hline 1 & 4.088498 & 100.0000 & 0.000000 & 0.000000 & 0.000000 & 0.000000 \\
2 & 5.655295 & 98.52493 & 0.014552 & 1.154203 & 0.255570 & 0.050743 \\
3 & 6.873658 & 95.69355 & 0.012162 & 2.902828 & 1.265241 & 0.126217 \\
4 & 7.935738 & 92.47215 & 0.018289 & 4.856258 & 2.447356 & 0.205947 \\
5 & 8.901140 & 89.22242 & 0.037516 & 6.785337 & 3.656646 & 0.298082 \\
6 & 9.800353 & 86.13212 & 0.064055 & 8.578613 & 4.833099 & 0.392109 \\
7 & 10.64717 & 83.32209 & 0.095145 & 10.18841 & 5.913762 & 0.480593 \\
8 & 11.44968 & 80.82200 & 0.127029 & 11.60814 & 6.881262 & 0.561574 \\
9 & 12.21348 & 78.62172 & 0.157768 & 12.84913 & 7.737121 & 0.634264 \\
10 & 12.94272 & 76.69588 & 0.186505 & 13.92993 & 8.488924 & 0.698758 \\
11 & 13.64078 & 75.01290 & 0.212833 & 14.87093 & 9.147643 & 0.755695 \\
12 & 14.31054 & 73.54093 & 0.236673 & 15.69158 & 9.724937 & 0.805876 \\
13 & 14.95454 & 72.25057 & 0.258126 & 16.40940 & 10.23178 & 0.850120 \\
14 & 15.57502 & 71.11579 & 0.277372 & 17.03959 & 10.67804 & 0.889202 \\
15 & 16.17398 & 70.11408 & 0.294623 & 17.59514 & 11.07234 & 0.923819 \\
16 & 16.75320 & 69.22625 & 0.310095 & 18.08702 & 11.42206 & 0.954583 \\
17 & 17.31426 & 68.43604 & 0.323992 & 18.52445 & 11.73350 & 0.982020 \\
18 & 17.85860 & 67.72973 & 0.336503 & 18.91519 & 12.01199 & 1.006584 \\
19 & 18.38748 & 67.09577 & 0.347795 & 19.26573 & 12.26204 & 1.028660 \\
20 & 18.90204 & 66.52441 & 0.358017 & 19.58153 & 12.48746 & 1.048575 \\
\hline
\end{tabular}

SBMK dan SBI memiliki kontribusi rata-rata yang terendah pada besaran IHK dibanding dengan variabel LOAN dan PUAB walaupun trend SBMK dan SBI cenderung meningkat stabil dari dari periode kedua sampai duapuluh. Rendahnya kontribusi SBMK dalam mempengaruhi IHK menunjukkan tingkat SBMK bukan menjadi faktor yang menentukan nasabah untuk mengajukan kredit di bank. Tingkat kredit di bank lebih dipengaruhi oleh jenis usaha nasabah dan kondisi ekonomi secara umum sehingga tingkat SBMK bukan menjadi pertimbangan utama bagi nasabah untuk mengajukan kredit di bank. Oleh karenanya, kebijakan ekspansif BI dengan mempengaruhi SBI relatif rendah pengaruhnya terhadap inflasi. Hal ini menunjukkan bahwa SBI bukan menjadi acuan utama bagi pihak perbankan untuk menentukan tingkat bunga yang dikeluarkan.

\section{FEVD transmisi kebijakan moneter syariah}

Variance decomposition (VD) pada transmisi kebijakan moneter syariah untuk mengetahui kontribusi variabel SBIS, FINC, PUAS dan IHMK terhadap perubahan IHK pada beberapa periode mendatang. Tabel 11, analisis VD menunjukkan bahwa variabel yang diperkirakan akan memiliki kontribusi paling besar terhadap IHK pada duapuluh bulan kedepan adalah IHK sendiri yang diikuti oleh kontribusi FINC, PUAS, IHMK dan kemudian SBIS. Dilihat dari trend setiap periode pada variace decomposition menunjukkan bahwa trend IHK cenderung turun dari periode ke periode. Sedangkan trend FINC, PUAS, IHMK dan SBIS cenderung mengalami kenaikan dari periode ke periode.

Besarnya kontribusi FINC terhadap IHK dapat dilihat dari besaran trend dari periode 1 sampai periode 20. Besaran kredit yang dikeluarkan bank konvensional mendorong berdampak bagi peningkatan output produksi. Meningkatnya output produksi menurunkan harga barang dan jasa sehingga meningkat permintaan. Keadaan ini akan mempengaruhi menurunkan nilai uang terhadap barang sehingga menjadi jumlah uang beredar (JUB) bertambah dan inflasipun meningkat. Sementara FINC, PUAS merupakan variabel yang memberikan 
kontribusi terhadap besaran IHK. Trend IHK yang meningkat relatif stabil dari dari bulan kedua sampai bulan keduapuluh.

IHMK dan SBIS memiliki kontribusi rata-rata yang terendah pada besaran IHK dibanding dengan variabel FINC dan PUAS walaupun trend IHMK dan SBIS cenderung meningkat stabil dari dari periode kedua sampai duapuluh. Rendahnya kontribusi IHMK dalam mempengaruhi IHK menunjukkan tingkat IHMK bukan menjadi faktor yang menentukan nasabah untuk mengajukan pembiayaan di bank. Jumlah pembiayaan lebih dipengaruhi oleh kondisi ekonomi secara umum sehingga tingkat IHMK bukan menjadi pertimbangan utama bagi nasabah untuk mengajukan pembiayaan di bank. Oleh karenanya, kontribusi SBIS relatif rendah terhadap inflasi karena SBIS bukan menjadi acuan utama bagi bank syariah untuk menentukan tingkat imbal hasil pada pembiayaan.

Tabel 10. Variance Decomposition Transmisi Moneter Syariah

\begin{tabular}{ccccccc}
\hline Period & S.E. & IHK & SBIS & FINC & PUAS & IHKM \\
\hline 1 & 0.952988 & 100.0000 & 0.000000 & 0.000000 & 0.000000 & 0.000000 \\
2 & 4.339154 & 9.075614 & 0.608858 & 90.08888 & 0.205868 & 0.020778 \\
3 & 6.049083 & 7.377911 & 0.319900 & 89.31115 & 2.513396 & 0.477638 \\
4 & 7.341261 & 6.268655 & 0.233884 & 87.18164 & 5.396407 & 0.919416 \\
5 & 8.533223 & 5.363616 & 0.179533 & 84.28073 & 8.650514 & 1.525611 \\
6 & 9.637542 & 4.713329 & 0.155410 & 82.29375 & 10.72509 & 2.112418 \\
7 & 10.66240 & 4.267503 & 0.158101 & 80.99963 & 12.05491 & 2.519855 \\
8 & 11.61183 & 3.955044 & 0.169836 & 80.09805 & 12.98195 & 2.795111 \\
9 & 12.49293 & 3.724778 & 0.186600 & 79.37123 & 13.72044 & 2.996952 \\
10 & 13.31770 & 3.545874 & 0.204050 & 78.76399 & 14.32971 & 3.156374 \\
11 & 14.09586 & 3.402729 & 0.221270 & 78.25961 & 14.82998 & 3.286417 \\
12 & 14.83447 & 3.286389 & 0.237321 & 77.84417 & 15.23918 & 3.392945 \\
13 & 15.53865 & 3.190451 & 0.251926 & 77.49904 & 15.57793 & 3.480652 \\
14 & 16.21254 & 3.110119 & 0.264988 & 77.20740 & 15.86361 & 3.553885 \\
15 & 16.85959 & 3.041835 & 0.276596 & 76.95724 & 16.10826 & 3.616069 \\
16 & 17.48276 & 2.983055 & 0.286895 & 76.74044 & 16.31999 & 3.669619 \\
17 & 18.08451 & 2.931930 & 0.296044 & 76.55114 & 16.50467 & 3.716213 \\
18 & 18.66690 & 2.887074 & 0.304193 & 76.38467 & 16.66697 & 3.757095 \\
19 & 19.23168 & 2.847407 & 0.311475 & 76.23723 & 16.81065 & 3.793235 \\
20 & 19.78035 & 2.812080 & 0.318007 & 76.10576 & 16.93874 & 3.825414 \\
\hline
\end{tabular}

Hasil variance decomposition pada transmisi kebijakan moneter konvensional dan syariah menunjukkan bahwa dua model variabel transmisi kebijakan moneter memiliki kecenderungan yang sama terhadap tingkat inflasi (IHK). Trend LOAN, PUAB, SBMK dan SBI pada transmisi kebijakan moneter konvensional dalam mempengaruhi IHK memiliki kecenderungan yang sama dengan trend FINC, PUAS, IHKM dan SBIS terhadap IHK dari periode ke-1 sampai ke-20. Keadaan ini menunjukan bahwa transmisi kebijakan moneter konvensional dan syariah saling berhubungan. Dengan kata lain, besaran instrumen moneter syariah masih dipengaruhi oleh besaran instrumen moneter konvensional. Keadaan ini ini menunjukkan bahwa kebijakan moneter syariah belum sepenuhnya independen dalam mempengaruhi besaran inflasi.

\section{Kesimpulan}

Berdasarkan hasil penelitian yang telah dilakukan mengenai mekanisme transmisi moneter konvensioal pada impulse respon menunjukkan bahwa respon IHK positif terhadap goncangan di IHK sendiri dan SBMK. Sementara itu, IHK merespon negatif terhadap goncangan pada SBI, LOAN dan PUAB. Tingkat suku bunga mempengaruhi tingkat produksi yang berdampak pada peningkatkan permintaan barang dan jasa. Apabila permintaan barang dan jasa meningkat maka meningkatkan besaran inflasi. 
Sementara itu, inflasi merespon tingkat positif terhadap tingkat SBI, LOAN dan PUAB pada periode 2010-2016. BI melakukan operasi pasar terbuka salah satunya dengan menawarkan SBI dengan tujuan pengendalikan nilai rupiah. BI menurunkan tingkat inflasi dengan meningkatkan tingkat bunga SBI, peningkatkan bunga SBI akan meningkatkan tingkat bunga antar bank (PUAB) dan bunga pinjaman (LOAN). Dan, dari hasil penelitian pada periode yang sama meningkatnya SBI, PUAB dan LOAN akan peningkatan inflasi.

Hasil impulse respon terhadap mekanisme transmisi syariah menunjukkan bahwa IHK merespon positif terhadap goncangan FINC dan IHMK. Kenaikan pembiayaan pada bank syariah yang disalurkan sebagian besar pada pembiayaan konsumtif. mempengaruhi peningkatan inflasi. Volume pembiayaan yang relatif lebih sedikit dibanding dengan bank konvensional menunjukkan bahwa kontribusi pembiayaan terhadap inflasi cukup rendah. Demikian pula dengan respon positif IHKM terhadap inflasi karena tingkat inflasi relatif stabil pada periode penelitian berlangsung sehingga tingkat IHMK tidak berpengaruh langsung terhadap tingkat inflasi.

Di lain pihak, IHK merespon negatif terhadap goncangan SBIS dan PUAS. Respon ini menunjukkan bahwa bahwa kenaikan SBIS mempengaruhi turunnya IHK atau sebaliknya. Tingkat imbal hasil SBIS menjadi pertimbangan manajemen bank syariah untuk menentukan nilai nisbah bagi hasil atau margin pembiayaan. Tingkat imbal hasil pembiayaan akan mempengaruhi produkstifitas perusahaan dan mempengaruhi tingkat inflasi. Di lain pihak, bank syariah memiliki kecukupan likuiditas dalam menjalankan kegiatan bank sehingga bank syariah kurang memanfaatkan PUAS. Keadaan ini yang menjadikan respon negatif IHK terhadap tingkat PUAS relatif lemah dikarena PUAS bukan instrumen utama yang digunakan manajemen bank syariah untuk mengatasi likudititas.

Analisis variance decomposition menunjukkan bahwa LOAN merupakan variabel yang memiliki kontribusi tertinggi diantara variabel lain yang mempengaruhi IHK. Tingkat inflasi selain dipengaruhi oleh faktor biaya yang tinggi juga karena jumlah meningkatnya jumlah permintaan masyarakat yang disebabkan oleh kenaikan pendapatan masyarakat. Dalam jangka pendek, pinjaman bank konvensional mempengaruhi inflasi melalui di jalur biaya, dan mempengaruhi permintaan barang dan jasa dalam jangka panjang. Dilihat dari trend trend LOAN cenderung mengalami kenaikan demikian pula dengan trend PUAB, SBMK dan SBI cenderung mengalami kenaikan dari periode ke periode.

Bila dalam hasil variance decomposition pada transmisi moneter konvensional menunjukkan bahwa pinjaman merupakan variabel yang paling berpengaruhi dibanding dengan PUAB, SBMK dan SBI, sedangkan pada variance decomposition pada transmisi moneter syariah menunjukan pembiayaan paling berpengaruh dibanding variabel lain. Berdasarkan tingkat besarnya pengaruh terhadap inflasi setelah FINC adalah PUAS kemudian IHMK dan SBIS. Pola pengaruh variabel-variabel dalam model transmisi moneter konvensional dan syariah hampir sama terhadap besaran inflasi (IHK). Kenyataan ini menunjukkan bahwa transmisi kebijakan moneter syariah di negara kita masih dipengaruhi oleh arah transmisi kebijakan moneter konvensional.

\section{Daftar Pustaka}

Ascarya (2007). Optimum Monetary Policy under Dual Financial/Banking System. Islamic Economics Conference (IECONS 2007). Kuala Lumpur: Universiti Sains Islam Malaysia, 17-19 Juli.

Ascarya. (2012). Alur Transmisi dan Efektifitas Kebijakan Moneter Ganda di Indonesia. Buletin Ekonomi Moneter dan Perbankan, 14(3), 283-315.

Enders, W. (2004). Applied Econometric Time Series . 2nd Edition. New York: John Wiley \& Sons.

Gujarat, D. (2004). Basic Econometric, 4th Edition, New York: McGraw-Hill.

Hasanah, H. Ascarya \& Achsani, N.A (2008), Perilaku Agregat Moneter dalam Sistem Keuangan/Perbankan Ganda di Indonesia, Jurnal Ekonomi dan Bisnis Indonesia, 23(2), 143-163.

Hasibuan, S \& Pratomo, W.A. (2015). Mekanisme Transmisi Kebijakan Moneter Melalui Suku Bunga SBI sebagai Sasaran Operasional Kebijakan Moneter dan Variabel Makroekonomi Indonesia, Jurnal Ekonomi dan Keuangan, 1(12), 27-40.

Kobayashi, T. (2008). Incomplete Interest Rate Pass-Through and Optimal Monetary Policy, International Journal of Central Banking, 4(3), 77-119.

Magdalena, I \& Pratomo, W.A. (2013). Analisis Efektivitas Transmisi kebijakan Moenter Ganda di Indonesia, Jurnal Ekonomi dan Keuangan, 2(11), 657-671.

Noviasari, A. (2012). Efektifitas Mekanisme Transmisi Kebijakan Moneter Ganda di Indonesia, Media Ekonomi, $20(3), 23-48$. 
Natsir. (2011). Analisis Empiris Efektivitas Mekanisme Transmisi Kebijakan Moneter di Indonesia Melalui Jalur Suku Bunga, Majalah Ekonomi, 21(2), 110-123.

Rusydiana, A.S. (2009). Mekanisme Transmisi Syariah Pada Sistem Moneter Ganda di Indonesia, Buletin Ekonomi Moneter dan Perbankan, 11(4): 345-367.

Rasbin \& Hermawan, I, (2013), Analisis Shock Kebijakan Moneter dalam Perekonomian Terbuka; Kasus Dua Sektor Ekonomi di Indonesia, Jurnal Ekonomi \& Kebijakan Publik, 4(1), 1-14.

Siamat, D. (2010) Manajemen Lembaga Keuangan; Kebijakan Moneter dan Perbankan. Jakarta: Penerbit Universitas Indonesia (UI).

Sudarsono, H. (2008). Bank dan Lembaga Keuangan Syariah; Deskripsi dan Ilustrasi, Yogyakarta: Ekonesia.

Sugianto, Harmain, H, \& Harahap, N (2015) Mekanisme transmisi kebijakan Moneter di Indonesia Melalui Sistem Moneter Islam, Human Falah, 2(1), 50-74.

Tai, PN \& Sek, S,K. (2011). Interest Rate Pass-Through and Monetary Transmission in Asia, International Journal of Economics and Finance, 4(2), 163-174.

Yan, Y \& Samba, M.C (2010). Interest Rate Pass-Through in the Central African Economics and Monetary Community (CAEMC) Area: Evidence from an ADRL Analysis, International Journal of Business and Management, 5(1), 31-41.

Tang, M.M, Puah, C \& Liew, V.K (2015) The Interest rate Pass-Through in Malaysia: An Analysis on Asymmmetric Adjusment, International Journal of Economics and Management, 9(2), 370-381.

Utama, C \& Septiani, R, 2017, Interest Rate Pass-Through: The Case of Indonesia, Siqnifikan: Jurnal Ilmu Ekonomi, 6(2), 345-356.

Pohan, A, (2008), Kerangka Kebijakan Moneter dan Implementasinya di Indonesia, Jakarta: PT Raja Grafindo Persada.

Warjiyo, P (2004).Mekanisme Transmisi Kebijakan Moneter di Indonessia, Jakarta: Pusat Pendidikan dan Studi Kebanksentralan (PPSK) Bank Indonesia.

Widayat, W.S., Tjahyono, E.D., Kusmiarso,B., Agung, Juda., Budiman. (2002). Perumusan Kerangka Kerja Kebijakan Moneter Inflation Targeting Dengan Suku Bunga Sebagai Target Operasional. Jakarta: Direktorat Riset Ekonomi dan Kebijakan Moneter Bank Indonesia Bank Indonesia. 